\title{
Does Institutional OUtPerform Retail? Performance Comparisons of Mutual Funds Using Traditional Measures
}

\author{
Mehmet Sencicek
}

Mehmet Sencicek, Associate Professor of Economics and Finance, Department of Business and Economics, School of Business and Justice Studies, Utica College, mesencic@utica.edu

\begin{abstract}
Institutional Mutual Funds cater to institutional investors and are different from retail mutual funds in several important aspects including a closer relationship between the fund manager and the better informed institutional investors who use sophisticated investment criteria, large and discrete inflow of funds, and much higher minimum initial and subsequent investment. There is a substantial amount of literature on retail mutual fund characteristics and performance, but despite their differences from retail funds, Institutional Mutual Funds have received little attention. In this study, Institutional Mutual Fund performance was evaluated in the nine different styles based on Morningstar's style box and compared to those of their counterparts using established traditional models and appropriate benchmarks. The results suggest institutional funds tend to outperform retail funds in the large-
\end{abstract}


cap categories in all measures; the evidence is mixed for midcap and small-cap categories.

Keywords: Institutional Mutual Funds, Mutual Fund Performance, Fund Performance Measures

\section{JEL Classification: G11, G23}

DOI: http://dx.doi.org/10.15239/j.brcacadjb.2018.08.01.ja03

\section{INTRODUCTION AND LITERATURE REVIEW}

The mutual fund industry has experienced a tremendous growth in the last few decades and has become one of the principal financial intermediaries controlling \$16.3 trillion in assets as of the end of 2016 (ICI Fact Book, 2017). While $5.7 \%$ of U.S. households owned mutual funds in 1980 , this number increased to $46.3 \%$ in 2016 . At the same time, the diversity of funds has increased allowing investors to choose from funds that hold assets ranging from relatively safe short term instruments to risky stocks domestically or internationally. This growing interest in mutual funds has taken place despite numerous academic studies showing that actively managed funds perform as well as a market index at best, and often under-perform (e.g. Jensen (1968), Malkiel (1995), Gruber (1996), and Carhart (1997)). There has been a parallel growth of interest in mutual funds by institutional investors including corporations, not-for-profit organizations, endowments, foundations, municipalities, and especially retirement plans, due in great part to the bullish stock market since the mid-1990s, except around the financial crisis of 2008. As an example, defined contribution retirement plans had $55 \%$ of their assets in mutual funds as of December 2016 (ICI fact Book 2017). The fund companies have responded to the growing interest by offering more and more funds geared towards institutional investors. While $\$ 206$ billion of retirement assets were invested in institutional mutual funds in 1990, this rose to $\$ 2,158$ billion in 2016 , a $947 \%$ increase in 26 years. 
The concept/term of institutional mutual fund may be viewed as an oxymoron since mutual funds were originally intended to provide small individual investors the expertise and purchasing power that large investors, such as institutional investors, can afford. The explanation for this seemingly contradictory phenomenon lies in the fact large investors such as defined contribution retirement plans, whose popularity has risen in recent years, hold a significant portion of their assets as mutual funds. As an example, mutual funds constituted $55 \%$ of the assets of defined contribution plans in 2016, compared to $9 \%$ in 1990. These developments have given impetus to the growth of institutional mutual funds. Mutual fund investing in domestic securities have remained the fund type of choice by all defined contribution plans representing the majority type in each year between 1996 and 2016 (ICI Mutual Fund Factbook, 2003 and 2017).

The relevant types of fund for institutional investors such as employer sponsored retirement plans, endowments, foundations, are the institutional (mutual) funds which are significantly different from other "regular" or "retail" mutual funds in several respects. One difference is that the institutional investors have a closer relationship with the fund manager, and the presumably sophisticated institutional investors closely monitor the performance of a fund manager. In their paper titled "Investor monitoring and differences in mutual fund performance", James \& Karceski (2006) found that institutional investors $d o$, in fact, closely monitor the fund manager's performance. Another important difference arises in the sensitivity of fund flows. In "Costly Search and Mutual Fund Flows", Sirri \& Tufano (1998) demonstrate that retail investors, who face high cost and information costs, "chase returns, flocking to funds with the highest recent returns". Harless \& Peterson (1998) find similar results, and argue that this behavior, which does not take risk and expenses into account, coupled with extremely slow adjustment of fund holdings, allows poorly performing mutual funds to persist. In contrast, flows into institutional funds are sensitive to measures such as risk adjusted returns; institutional investors, not facing high search costs, can focus 
on more sophisticated investment selection criteria, and punish poorly performing managers by withdrawing assets (e.g., Del Guercio and Tkac 2002; Goyal andWahal 2008). A recent study (Evans \& Fahlenbrach, 2012) similarly found that institutional investor flows were more sensitive to poor risk-adjusted performance than retail flows, and retail investors responded more strongly to counterproductive signals like past total (not risk adjusted) return. A third difference is the discrete and large inflows into institutional funds compared to continuous and small inflows of retail funds. Finally, institutional funds require higher minimum initial and subsequent investments, often in millions and hundreds of thousands of dollars, respectively, putting them out of the reach of most individual investors. As such, institutional funds cater to institutional investors. Some funds labeled as "institutional" cater to the individual investors by selling shares through brokers; these funds typically have a much lower minimum initial and subsequent investment requirements, and therefore are not considered "institutional" for the purposes of this study.

Given that the relatively more sophisticated institutional investors can closely monitor fund managers, use risk adjusted measures and can punish poor performance by moving funds, institutional funds have a stronger incentive to produce better returns, and poor performance should not persist. Cremers et al (2009) do indeed find that, as manager incentives increase and interests become more aligned with investor interests, fund performance increases. This, in turn, should theoretically increase the average performance of institutional funds relative to retail funds. Grossman and Stiglitz's (1980) model of market efficiency predicts that informed investors earn higher returns than uninformed investors. Do institutional mutual funds, which cater to informed investors, outperform retail mutual funds that are otherwise comparable in investment styles?

Performance evaluation of retail mutual funds has been studied extensively for some time (e.g. Jensen, 1968; Grinblatt and Titman, 1992 \& 1993; Brown and Goetzmann, 1995; Malkiel, 1995; Ferson and Schadt, 1996; Gruber, 1996; Carhart, 1997), and continues to be of interest to investors 
and scholars (e.g. Guercio and Reuter, 2014). Despite their dramatic growth both in the number of funds and assets under management, institutional mutual funds have received little special attention. The sparse literature on the topic includes a study by Evans and Fahlenbrach (2012) that finds retail funds with an institutional "twin" outperform other retail funds presumably benefiting from the advantage of better management of an institutional fund due to differences between the two classes. Baker and Haslem (2009) study the relationship between characteristics and performance of institutional equity funds, but do not compare institutional and retail fund performance. Similarly, Bird et al (2011) examine the connection between the management's active decisions and the subsequent performance outcomes in institutional funds, but do not address performance differences with retail funds.

The aim of this study is to contribute to the performance evaluation of this growing segment of mutual funds geared towards a fast growing market of retirement plans and other institutional investors. The research question is "Do the well-established differences between institutional and retail mutual funds result in performance differences?" For this, the study uses the three "traditional" measures of fund performance to evaluate the performance of institutional mutual funds relative to their appropriate benchmarks and compare their performance to those retail funds in each of the nine Morningstar ${ }^{\circledR}$ fund categories. The rest of the paper is organized as follows: section 2 reviews and discusses the "traditional" measures of fund (portfolio) performance; section 3 describes the data and methodology; section 4 presents results and conclusions. Tables and detailed formulas are presented in the Web appendix.

\section{A REVIEW OF THE TRADITIONAL MEASURES OF PERFORMANCE}

The most well-known definition of risk with knowable probabilities is due to Frank Knight. In his book based on his dissertation "Risk, Uncertainty and Profit" (1921), Knight made his famous distinction between "risk" 
and "uncertainty" (randomness with unknowable probabilities). In an effort to provide a theoretical underpinning for profit, he argued that profit existedbecause actual competition in a modern industrial economy differed from competition in the world of pure competition in one essential regard: competitors in modern economies operated in a world of uncertainty; competitors in pure competition faced risk, but not uncertainty. Facing uncertainty made competitors become entrepreneurs as they had to use their critical judgment for decision-making.

Two most commonly of the several variables used to assess risk in performance evaluation are beta and standard deviation. The beta for (the manager of) a fund $(\beta p)$ is the covariance of the fund's risk premium with the benchmark's risk premium divided by the variance of the benchmark's risk premium. In economic terms, beta reflects a fund's volatility relative to the market or the only market-related portion of a fund's risk (systematic or undiversifiable risk) rather than the total risk (represented by standard deviation of the fund's returns) which includes both systematic and unsystematic risk. The following example illustrates the interpretation of beta: If beta equals 1.0 for a particular fund, then it matched the market. If beta equals 1.25 then it did $25 \%$ better in a bull market and $25 \%$ worse in a bear market.

Beta can also be calculated as follows:

- Periodic returns for both the fund and the relative benchmark are calculated.

- These returns are converted to risk premiums (or excess returns over the risk free rate of return on a T-Bill).

- A scatter chart of the risk premiums is produced and the line which best fits the observations is estimated using least squares linear regression using the regression equation below:

$$
\left(R_{p t}-r_{t}\right)={ }_{p}+\beta_{p}\left(R_{b t}-r_{t}\right)+t_{t}
$$

where $R_{p t}, R_{b t}$ and $r_{t}$ are the fund's return, the benchmark's return and the risk free rate, respectively. 
Another commonly used measure of risk, standard deviation measures the volatility of returns around their average. Standard deviation is not dependent on an index, and therefore can be used to compare funds across asset classes. Since it is a measure of total risk, both systematic and unsystematic, it captures risk more comprehensively than beta. Standard deviation can be calculated readily through a software package or a program such as Microsoft Excel, or by the formula given in the appendix. A third measure, "alpha", is a measure of the differential earned in an average period, given the fund's systematic risk (Beta). It is estimated by regressing fund returns against benchmark returns.

\section{Portfolio Theory}

The first rigorous method applicable to mutual fund evaluation was due to Markowitz's Mean-Variance Portfolio Theory (1952, 1959). Prior to Markowitz's paper "Portfolio Selection" (1952), standard investment advice was to construct a portfolio from securities that offered the best opportunities for gain with the least risk which could lead to a portfolio of assets all from a single sector. Markowitz formalized the intuition that such a portfolio would be 'foolish' and provided the case for diversification. Instead of merely compiling portfolios from securities that each individually have attractive risk-reward characteristics, he proposed selecting a portfolio based on the overall risk-reward characteristics of the portfolio itself!

William Sharpe introduced the Capital Asset Pricing Model (CAPM) in 1964; Lintner (1965), and Mossin (1966) performed parallel work. CAPM extended Markowitz's portfolio theory by introducing systematic and specific risk. Sharpe later received the 1990 Nobel Prize in Economics for his work on CAPM, which he shared with Harry Markowitz and Merton Miller. In this model, if investors have homogeneous expectations and optimally hold mean-variance efficient portfolios, then, in the absence of market friction, the market portfolio itself will be a mean-variance efficient portfolio. In equilibrium, all investors will hold combinations of the market portfolio of risky assets and the risk-free asset. The expected 
return on an asset is a linear function of the asset's systematic risk, beta: the expected return of an asset equals the risk-free rate plus the portfolio's beta multiplied by the expected excess return of the market portfolio.

$E\left(R_{i}\right)=R_{f}+\left[E\left(R_{m}\right)-R_{f}\right]_{i}$

where,

$\mathbf{E}\left(\mathbf{R}_{\mathbf{i}}\right)$ is the expected return on the $\mathrm{i}^{\text {th }}$ asset,

$\mathbf{R}_{\mathbf{f}}$ is the risk-free rate,

$\mathbf{E}\left(\mathbf{R}_{\mathrm{m}}\right)$ is the expected return on the market portfolio.

$\mathrm{i}=\operatorname{Cov}\left(\mathrm{R}_{\mathrm{i} ;} \mathrm{R}_{\mathrm{m}}\right) / \operatorname{Var}\left(\mathrm{R}_{\mathrm{m}}\right)$ is the systematic risk of asset $\mathrm{i}$. It measures the volatility of the security, relative to the market.

If we Let $\mathrm{R}_{\mathrm{p}}$ be a portfolio's simple return, and let now denote the portfolio's beta, we obtain

$$
E\left(R_{p}\right)=R_{f^{+}}\left[E\left(R_{m}\right)-R_{f}\right]
$$

The essential conclusion of CAPM is that a stock's (or portfolio's) excess expected return depends on its beta and not its volatility, in other words, on systematic risk and not on total risk. The market compensates investors for taking systematic risk but not for taking specific risk which can be diversified away. In the market portfolio, each individual asset in that portfolio has specific risk, diversification reduces the investor's net exposure to just the systematic risk of the market portfolio. Given a beta and an expected return for an asset, investors will bid its current price up or down, adjusting that expected return so that it satisfies the CAPM equation. Accordingly, the CAPM predicts the equilibrium price of an asset. This works because the model assumes that all investors agree on the beta and expected return of any asset. In practice, this assumption is unreasonable, so the CAPM is largely of theoretical value. It is the most famous example of an equilibrium pricing model. 
A one factor model, CAPM describes a linear relationship between expected returns and systematic risk as measured by 'beta', the idea being that investors demand additional expected return (called 'the risk premium') to accept additional risk. It provides a benchmark against which mutual funds and actively managed portfolios can be evaluated. CAPM continues to be the most widely used portfolio evaluation tool in MBA classes and by finance practitioners despite its highly restrictive and theoretical assumptions, and the wide criticism leveled by academicians and proponents of other methods (e.g. Fama and French, 1996). The risk adjusted performance measures used in this study were based on Capital Asset Pricing Model and Markowitz's Portfolio Theory: the Treynor Index (1965), the Sharpe Ratio (1966) and Jensen's 'alpha' (1968). All three measures try to reduce the risk-reward dimensions of portfolio performance to a single measure that indicates a risk-adjusted return.

\section{Treynor Index}

Treynor (1965) incorporated risk into a performance measure by considering the portfolio's rate of return with respect to the market rate of return. Like Sharpe Ratio explained below, Treynor index also measures a portfolio's excess return per unit of risk, but uses portfolios beta instead of the standard deviation of returns used by Sharpe ratio. Thus, it is the ratio of the portfolio's rate of return minus the risk-free rate of return to the portfolio's beta. According to Treynor's model, there are two components of risk: 1). Risk produced by general market fluctuations, and 2). Risk resulting from unique fluctuations in the securities within the portfolio. To identify risk due to market fluctuations, Treynor introduced the characteristic line, which defines the relationship between the rates of return for a portfolio and the rates of return for an appropriate market portfolio. The slope of the characteristic line is the portfolio's beta coefficient and it measures the relative volatility of the portfolio's returns in relation to returns for the aggregate market. A higher slope (beta) indicates a portfolio that is more sensitive to market returns. 


\section{The BRC Academy Journal of Business Vol. 8, No. 1}

In an attempt to circumvent risk preferences of investors in developing a measure of performance and using the Capital Asset Pricing Theory as a basis, Treynor developed a straight portfolio possibility line by combining a risk-free asset with different portfolios. He argued that rational, riskaverse investors would always prefer portfolio possibility lines with higher slopes as they would put investors on higher indifference curves. The Treynor index, reward-to-volatility ratio, is the ratio of the fund's excess return divided by the fund's beta (see formula in the Appendix). The numerator of the ratio, fund's average return over the average of the risk free rate, is the risk premium. The risk-free rate of return is simply the current rate of return on risk-free assets, like Treasury Bills. For a mutual fund, the risk premium is the difference between the fund's average return and the average return on a risk-free asset over the same time period. This risk premium represents the amount of compensation that risk-averse investors expect to earn for the additional risk undertaken through the purchase of risky assets. To buy into a fund, the risk-averse investor will require the "risk premium" which captures the uncertainty of buying individual funds. The denominator of Treynor's index is a measure of the fund (portfolio)'s risk; thus, Treynor index is a measure of the portfolio's risk premium return per unit of risk. Accordingly, a large Treynor Index indicates a larger slope and a better portfolio (higher indifference curves) for all investors, regardless of their risk preferences. In this model, beta measures systematic risk, which is the relevant risk measure for a completely diversified portfolio, as is implicitly assumed.

\section{Sharpe Ratio and Jensen's 'Alpha'}

The Sharpe Ratio, which uses the capital market line as a benchmark, is defined as the ratio of a portfolio's return in excess of the risk-free rate to the portfolio's standard deviation of returns over a period (Sharpe 1966, 1975). The numerator is identical to that of Treynor's index, what distinguishes them is that Sharpe ratio employs total risk associated with the portfolio (standard deviation of portfolio returns), not the portfolio beta (formula provided in the appendix). The Sharpe Ratio 
evaluates the ability of a portfolio manager on the basis of both rates of return performance and diversification by calculating the total risk of the portfolio using the standard deviation of returns. The Sharpe Ratio, as the slope of the line connecting the expected return of the portfolio with the risk-free rate, provides a convenient measure of the performance of mutual funds: steeper slopes, i.e. higher Sharpe Ratios indicate better investment performance, since investors can reach higher levels of expected utility as the slope of the transformation line connecting the risk-free rate and the point representing the risk-return characteristics of the mutual fund becomes steeper. Any portfolio that is positioned on the capital market line has a Sharpe Index equal to that of the market and, therefore, is characterized by neutral performance. This makes sense under the CAPM, because on the basis of public information alone, any investor can construct a portfolio that is positioned on the capital market line. A higher Sharpe ratio is more favorable because it indicates a higher return per unit of risk taken.

The third measure, Jensen's 'alpha' is also based on CAPM; it calculates the risk premium that a fund achieves over its expected return. In essence, Jensen's 'alpha' measures a fund manager's ability to deliver above-benchmark returns, adjusted for risk. A positive 'alpha' indicates consistently positive excess returns, while a negative 'alpha' means the fund has consistently underperformed its benchmark. A detailed description of Jensen's model is provided in the methodology section.

The above three measures above are known as the "traditional performance measures". Since they are based on Capital Asset Pricing Model, which assumes a single period investment horizon, Sharpe Index, Treynor Index and Jensen's model are single period models. In reality, investors have multiple investment horizons; this implies that the functional form of the relationship between expected returns and systematic risk will be nonlinear. Several other measures have been employed by scholars and to a lesser extent by finance practitioners, for fund and/or stock evaluation, including three-moment asset pricing model by Kraus and Litzenberger 
(1983), Fama and French (1993) three-factor model, Carhart (1997) fourfactor model, Fama and French (2015) five-factor model. Despite problems associated with all three, they are still the most widely used measures, by academicians and practitioners alike.

\section{DATA AND METHODOLOGY}

There are two well-known sources of mutual fund data, one by Morningstar Inc., and the other by the Center for Research in Security Prices $\left(\mathrm{CRSP}^{\circledR}\right)$, a financial research center at the University Of Chicago Graduate School Of Business. CRSP creates and maintains historical U.S. databases for mutual funds as well as stocks (NASDAQ, AMEX, NYSE), indices and bonds. One advantage the CRSP has is that its US Mutual Fund Database is survivor-bias free as it contains live funds as well as funds that have been discontinued. It has one important disadvantage, however, in that it is subject to omission bias. Elton et al (2001) compared CRSP Survivor Bias Free U.S. Mutual Fund Database to Morningstar's database. They found that the CRSP database's omission bias causes the same effects as survivorship bias. Although all mutual funds were listed in CRSP, return data were missing for many funds. They found the CRSP return data to be biased upward.

Morningstar mutual fund data and profiles are publicly available online at the Yahoo! Finance website, where historical prices can be downloaded free of charge. Although this dataset does not provide data on dead funds (and therefore has survivorship-bias), the historical prices are complete for the period they are available except for occasional missing daily prices. The profiles of the funds provide information on the current lead manager including his/her start date. Other relevant data include fund overview, fund summary, fund operations, fees and expenses and investment information including minimum initial and subsequent investment amounts required. 
Despite their impressive growth, institutional mutual funds are still a very small subset of mutual funds in terms of number of funds although growing interest by retirement plans has led to inception of numerous funds in this subset in recent years. Some funds, despite being labeled as Institutional Mutual Funds do (also) cater to the individual investors by selling shares through brokers; these funds typically have a much lower minimum initial and subsequent investment requirements, and therefore are not included in this study. All of the funds included invest primarily in domestic equities, have at least 10 years of historical prices available as of March 31 $1^{\text {st }}$, 2017, have minimum initial investment requirement of $\$ 100,000$ (most over $\$ 1$ million) and are designated as "Institutional" even if this qualifier is not in the fund's name. The fact that only funds with at least 10 years of life are chosen may lead to selection bias, and since dead funds are not included in the database, there is survivorship-bias in the data. Morningstar ratings and funds' fees and expenses are not considered.

Investment styles are considered in classification of funds into nine categories. The "style" of a fund or its manager refers to the approach fund managers use for security selection and is considered to have an influence on his/her performance. Morningtar's styles classification allocates funds into different categories based on fund's investment methodology and the market capitalization of the companies in which it invests. It places the funds in large-cap, medium-cap or small-cap categories based on the market capitalization of the companies whose equities the fund holds. Funds are also characterized as growth oriented, value oriented and blend. The combination of orientation and market capitalization yields nine categories: Large-Cap Growth, Mid-Cap Growth and Small-Cap Growth; Large-Cap value, Mid-Cap Value and Small-Cap Value; LargeCap Blend, Mid-Cap Blend and Small-Cap Blend. An illustration of the Morningstar Style Box can be seen in Web Appendix B.

Other classification methods have been offered; Brown and Goetzmann (1997) for example, proposed a classification based on returns without 
using any information about the composition of the fund's portfolio. As such, they classified equity funds into eight major categories: Growth and Income, Growth, Income, Value, Global Timing, Glamour, International and Metal Funds. However, Morningstar style box remains the most commonly used tool for fund classification.

If funds are divided into several categories, it makes little sense to compare the performances of all funds to a single benchmark, such as the S\&P 500 index. Instead, each fund should be compared to a benchmark that is compatible with its classification. Accordingly, this study uses nine different benchmarks one for each category of funds as shown in the appendix. Russell indexes are chosen because of their similarity in construction to Morningstar's style categorization and for the stated purposes of the style indexes: "to provide investors with accurate benchmarks for measuring [manager performance]". A list of the Russell indices appropriate for each Morningstar category is provided in Web Appendix B.

The dataset consisted of otherwise comparable institutional and retail funds. Institutional funds were chosen first for each of the nine Morningstar categories based on the criteria described above. Retail funds were then selected as follows: If a retail "twin" of an institutional funds was available, it was selected, if not, retail funds with otherwise comparable investment objectives to the included institutional funds were selected. As the first step of performance evaluation, monthly fund prices and benchmark indices were obtained from Yahoo! Finance website for the 10 year period between 2007 and 2017 and monthly returns $\left(R_{p t}\right)$ were computed in MS Excel ${ }^{\circledR}$ as a monthly percentage change in the fund's closing price (ACP) adjusted for dividends and splits. Monthly prices of the relevant benchmarks $\left(\mathrm{R}_{\mathbf{b t}}\right)$ and monthly returns were calculated in the same manner. A fund's risk premium (or excess return) in any month that is used to compute the Treynor Index and the Sharpe Ratio is the difference between the fund's return and the yield on 3-month Treasury Bill (r) (as proxy for the risk-free rate) for the same period: 
$\mathrm{RP}_{\mathrm{pt}}=\mathrm{R}_{\mathrm{pt}}-\mathrm{r}_{\mathrm{t}}$. Similarly, a benchmark's risk premium is its excess return over risk-free rate: $\mathrm{RP}_{\mathrm{bt}}=\mathrm{R}_{\mathrm{bt}}-\mathrm{r}_{\mathrm{t}}$.

Using this notation, Jensen's 'alpha' model is expressed as $\left(\mathrm{R}_{\mathrm{pt}}{ }^{-}\right.$ $\left.\mathrm{r}_{\mathrm{t}}\right)={ }_{\mathrm{p}}+\beta_{\mathrm{p}}\left(\mathrm{R}_{\mathrm{bt}}-\mathrm{r}_{\mathrm{t}}\right){ }_{\mathrm{t}}$, or $\mathrm{RP}_{\mathrm{pt}}=\mathrm{p}_{\mathrm{p}}+\beta \mathrm{p}(\mathrm{RPpt}){ }_{\mathrm{t}}$. where $\beta p$ is the fund's beta as previously discussed and $\mathrm{p}_{\mathrm{p}}$ is the fund's 'alpha'. When a fund's risk premium is regressed on the benchmark's risk premium, the intercept coefficient is Jensen's 'alpha'. If alpha is positive, the fund manager has outperformed the market. Treynor index is found by dividing the fund's excess return by its beta, and Sharpe ratio for a fund is computed as the ratio of the fund's average risk premium to the standard deviation (volatility) of its returns. Detailed formulas are provided in Web Appendix B.

\section{RESULTS AND CONCLUSIONS}

A growing segment of the mutual fund market, institutional funds cater to a fast growing market of retirement plans and other institutional investors. These funds differ from retail funds in important aspects that should affect their relative performance such much higher initial and subsequent investments, discrete and larger fund flows that are sensitive to risk adjusted measures rather than recent performance, and close monitoring by the relatively more sophisticated institutional investors. It is increasingly recognized that institutional investors (the principals) have the power to reduce the agency problem associated with investing through fund managers (the agents) and improve the governance of these companies (Lucian et al, 2017). According to Fama and Jensen (1983), the ability of investors to redeem shares represents market governance that they argue reduces the need for other forms of governance in mutual funds. Given their close monitoring and ability to withdraw funds more easily than retail investors, sophisticated institutional investors exercise market governance and punish poorly performing managers by withdrawing assets under management (e.g., Del Guercio and Tkac, 2002); and Goyal and Wahal, 2008). 
These significant differences in the two types of funds should theoretically result in performance differences as suggested by Grossman and Stiglitz's (1980) model of market efficiency predicts that informed investors earn higher returns than uninformed investors. To test this proposition, relative performances of institutional funds and retail funds were examined and compared in nine Morningstar style categories using the three traditional measures Treynor Index, Sharpe Ratio and Jensen's Alpha. All of the funds included in the study invest primarily in domestic equities, have at least 10 years of historical prices available as of January $31^{\text {st }}$, 2017, and institutional funds require a minimum initial investment of at least $\$ 100,000$ (most over $\$ 1$ million) and are designated as "Institutional" by Morningstar. Detailed results including returns, excess returns, fund's beta Treynor Index, Sharpe Ratio and Jensen's 'Alpha' are presented in Web Appendix A.

The results of the study suggest that Institutional funds that invested in large cap companies perform better overall than their retail counterparts across the three investment styles growth, value and blend. There were 36 possible comparisons ( 1 year, 3 year, 5 year and 10 year periods, three measures each for 3 orientation styles per period); institutional funds outperformed retails funds in 32 out of 36 comparisons. Interestingly, institutional fund performed better in all 12 comparisons in the Large Cap Growth category (in 9 and 11 comparisons, respectively, in the Value and Blend orientations). The performance differences between the fund classes were not as pronounced in the Small Cap categories although the institutional funds did outperform retail funds in 24 of the 26 comparisons ( 6 out of 12 in Value, 8 out of 12 in Growth, and 12 out of 12 in the Blend orientation). Strikingly, institutional funds underperformed retail funds in 25 out of the 36 comparisons across the Midcap category, although somewhat better in the Midcap Value orientation where they performed better in 7 counts. It should be noted, however, that the differences in performance across Midcap categories were small compared to those in the Large Cap and Small Cap categories. Further, Treynor Index stood out as the measure in which institutional funds invariably underperformed 
suggesting that fund betas might be relatively high in this category. In fact, a close examination revealed that institutional fund betas are relatively higher than retail fund betas in both Large Cap and Midcap categories, but significantly higher in the Midcap categories, with average beta for the institutional fund being almost $60 \%$ higher than that for the retail funds, compared to $46.7 \%$ in the large cap category. Interestingly, institutional funds had a lower average beta $(92.7 \%$ of that for the retail funds), which was consistent with superior Treynor Index in 8 out of 12 comparisons (4 time periods and 3 orientations).

Fund performances were also compared across investment orientations (Value, Growth and Blend) in measures, market capitalization and periods. Out of the 36 comparisons, institutional funds had superior performance in 22, 25 and 22 counts, respectively, in the Value, Blend and Growth orientation classifications, suggesting that investment orientation is not a factor that influences whether an institutional fund outperforms a retail fund. A similar result emerged in comparing performance over investment periods; institutional fund bringing in a better return in 27, 27, 26 and 25 comparisons over 1 year, 3 year, 5 year and 10 year investment periods, respectively. Accordingly, investment horizon does not appear to be a factor in relative performance of institutional funds.

Based on these results, one could cautiously argue that, overall, institutional funds do outperform retail funds as expected given their characteristics, most notably the close monitoring by the more informed institutional investors who exercise "market governance" through the use of sophisticated, risk adjusted performance measures to evaluate performance and determine fund flows. The performance difference is most pronounced in the Large Cap Categories of Morningstar classification, and especially in the Large Cap Growth and Blend categories. There is evidence that institutional funds perform better in Small Cap categories to a lesser extent. Surprisingly, results indicate that institutional funds underperform, albeit with small margins, in the Midcap categories except for the Value orientation in which performances were 
comparable. Considering the typically lower fees and expenses charged by institutional funds not considered in the study, the net returns of these funds are expected to be considerably higher than those of their retail counterparts.

\section{Limitations And Further Rese arch}

The Morningstar dataset used in the study has survivorship bias and the alternative dataset (CRSP) has omission bias. This study could be repeated with the alternative dataset to see if the same results would be obtained. If a dataset that is free of survivorship bias and omission bias can be obtained in the future, the study should be repeated with this superior dataset. Additionally, this study compared performance evaluation using the traditional measures based on their widespread use by scholars and finance practitioners. It could be repeated with other performance measures such as three-moment asset pricing model by Kraus and Litzenberger (1983), Fama and French (1993) three-factor model, Carhart (1997) four-factor model, Fama and French (2015) fivefactor model.

\section{REFERENCES}

Baker, H. K., Haslem, J. A., \& Smith, D. M. (2009). Performance and characteristics of actively managed institutional equity mutual funds. The fournal of Investing, 18(1), 27-44.

Bird, R., Pellizzari P., \& Yeung D. (2011). Performance Implications of Active Management of Mutual Funds. Paul Woolley Centre Working Paper, University of Technology, Sydney

Brown, S. J., \& Goetzmann, W. N. (1997). Mutual fund styles. fournal of financial Economics, 43(3), 373-399.

Carhart, M. M. (1997). On persistence in mutual fund performance. The fournal of Finance, 52(1), 57-82. 
Cremers, M., Driessen, J., Maenhout, P., \& Weinbaum, D. (2009). Does Skin in the Game Matter? Director Incentives and Governance in the Mutual Fund Industry. Journal of Financial and Quantitative Analysis, 44, 1345-1373

Del Guercio, D., \& Tkac, P. A. (2002). The determinants of the flow of funds of managed portfolios: Mutual funds vs. pension funds. fournal of Financial and Quantitative Analysis, 37(04), 523-557.

Elton, E. J., Gruber, M. J., \& Blake, C. R. (2001). A first look at the accuracy of the CRSP mutual fund database and a comparison of the CRSP and Morningstar mutual fund databases. The fournal of Finance, 56(6), 2415-2430.

Evans, R. B., \& Fahlenbrach, R. (2012). Institutional investors and mutual fund governance: Evidence from retail-institutional fund twins. Review of Financial Studies, 25(12), 3530-3571.

Fama, Eugene F., Kenneth R. French, 1993. Common risk factors in the returns on stocks and bonds. Fournal of Financial Economics 33, 3-56.

Fama, E. F., \& French, K. R. (1996). The CAPM is wanted, dead or alive. The fournal of Finance, 51(5), 1947-1958.

Fama E. F.\& French, K.R., (2015). A five-factor asset pricing model. fournal of Financial Economics, 116, 1- 22.

Fama, E.F., \& Jensen, M.C. (1983) Separation of ownership and control, Journal of Law and Economics 26, 301-325.

Goyal, A., \& Wahal, S. (2008). The selection and termination of investment management firms by plan sponsors. The fournal of Finance, 63(4), 1805-1847.

Grinblatt, M., \& Titman, S. (1992). The persistence of mutual fund performance, The Journal of Finance 47, 1977-1984.

Grinblatt, M., \& Titman, S. (1993). Performance measurement without benchmarks: An examination of mutual fund returns. Fournal of business, 47-68.

Grossman, S., \& Stiglitz, J. (1980). On the Impossibility of Informationally Efficient Markets. The American Economic Review, 70(3), 393-408. 
Gruber, Martin J. (1996). Another puzzle: The growth in actively managed mutual funds, The fournal of Finance 51, 783-810.

Guercio, D. D. and Reuter, J. (2014), Mutual Fund Performance and the Incentive to Generate Alpha. The fournal of Finance, 69: 1673-1704

Harless, D.W., \& Peterson, S.P. (1998). Investor behavior and the persistence of poorly-performing mutual funds fournal of Economic Behavior \& Organization, Vol. 37 257-276

Investment Company Institute. (2004). Mutual Funds: Total Net Assets Held in Individual and Institutional Accounts. Mutual Fund Fact book.

Investment Company Institute. (2016). Mutual Funds: Total Net Assets Held in Individual and Institutional Accounts. Mutual Fund Fact book.

James, C., \& Karceski, J. (2006). Investor monitoring and differences in mutual fund performance. Fournal of Banking \& Finance, 30(10), 2787-2808.

Jensen, M.C. (1968). The performance of mutual funds in the period 1945-1964. The fournal Finance 23, 389-416.

Jiang, G., Yao, T., Yu, T., 2007. Do mutual $\mathrm{f}$

Kraus, A., \& Litzenberger, R. (1983). On the distributional conditions for a consumption-oriented three moment CAPM. The fournal of Finance, 38(5), 1381-1391.

Knight, F. (1921). Risk, Uncertainty and Profit. New York, NY: Houghton Miflin Company.

Lintner, J. (1965). The valuation of risk assets and the selection of risky investments in stock portfolios and capital budgets. The review of economics and statistics, 13-37.

Lucian A. Bebchuk, Alma Cohen, and Scott Hirst (2017). The Agency Problems of Institutional Investors. Fournal of Economic Perspectives, Vol. 31, No. 3: 89-112

Malkiel, B. (1995) Returns from investing in equity mutual funds, The Journal of Finance 50, 549-572.

Markowitz, H. (1952). Portfolio selection. The fournal of Finance, 7(1), 77-91. 
Markowitz, H. (1959). Portfolio Selection, Efficent Diversification of Investments: J. Wiley.

Mossin, J. (1966). Equilibrium in a capital asset market. Econometrica: fournal of the econometric society, 768-783.

Schmidt, L., Timmermann, A., \& Wermers, R. (2016). Runs on money market mutual funds. The American Economic Review, 106(9), 2625-2657.

Sharpe, W. F. (1964). Capital asset prices: A theory of market equilibrium under conditions of risk. The fournal of Finance, 19(3), 425-442.

Sirri, E. R. \& Tufano,P. (1998). Costly search and mutual fund flows, Journal of Finance 53, 1589-1622.

Treynor, J. L. (1965). How to rate mutual fund performance. Harvard Business Review, 43, 63-75.

\section{Citation Information}

Sencicek, Mehmet. "Does Institutional Outperform Retail? Performance Comparisons of Mutual Funds Using Traditional Measures." The BRC Academy Journal of Business 8, no. 1 (2018): 45-65. http:// dx.doi.org/10.15239/j.brcacadjb.2018.08.01.ja03

\section{Web APPEndix}

A web appendix for this paper is available at: http://dx.doi.org/10.15239/ j.brcacadjb.2018.08.01.wa03 